\title{
CATALYTIC ACTIVITY OF TITANIA-SUPPORTED MANGANESE OXIDE CATALYST IN OZONE DECOMPOSITION
}

\author{
Batakliev Todor Todorov
}

Associate Professor, PhD, Institute of Catalysis of Bulgarian Academy of Sciences todor@ic.bas.bg

G. Boncheva St., 11, 1113 Sofia, Bulgaria

\section{Rakovsky Slavcho Kirilov}

Professor, D.Sc.,

Institute of Catalysis of Bulgarian Academy of Sciences

rakovsky@ic.bas.bg

G. Boncheva St., 11, 1113 Sofia, Bulgaria

\section{Zaikov Gennady Efremovich}

Doctor of Chemical Sciences, Professor,

Head of Department of Biological and Chemical Physics of Polymers, Institute of Biochemical Physics named after N.M. Emanuel

chembio@sky.chph.ras.ru

Kosygina St., 4,119334 Moscow, Russian Federation

\section{Georgiev Vladimir Ferdinandov}

Associate Professor, $\mathrm{PhD}$,

Institute of Catalysis of Bulgarian Academy of Sciences,

vlado@ic.bas.bg

G. Boncheva St., 11, 1113 Sofia, Bulgaria

\section{Anachkov Metodi Parvanov}

\author{
Associate Professor, $\mathrm{PhD}$ in Law, \\ Institute of Catalysis of Bulgarian Academy of Sciences \\ anachkov@ic.bas.bg \\ G. Boncheva St., 11, 1113 Sofia, Bulgaria
}

Abstract. The titania-supported Mn oxide system made by incipient wetness impregnation method was investigated in the reaction of heterogeneous catalytic decomposition of ozone. The catalytic activity of the catalysts containing 6,8 and $10 \mathrm{wt} \%$ manganese oxide was found using the decomposition coefficient $\gamma$ which is proportional to ozone decomposition rate. It was established that all catalytic samples are active towards ozone decomposition but the catalyst possessing 
$10 \mathrm{t} \% \mathrm{MnOx} / \mathrm{TiO} 2$ was the most active. The calculated values of $\gamma$ were in the range of $0.05 \times 10^{-4}$ $0.4 \times 10^{-4}$. The experiments were performed at the temperature range of $258 \mathrm{~K}$ to $313 \mathrm{~K}$ in a tube glass reactor. It was determined that the activation energy of the process is $11 \mathrm{~kJ} / \mathrm{mol}$. The catalyst was characterized by TPR, XRD, AFM, FT-IR spectroscopy and surface measurements. Acatalytic cycle of ozone decomposition on $\mathrm{MnOx} / \mathrm{TiO} 2$ catalyst was proposed.

Key words: ozone, titania, manganese oxide, decomposition, activation energy.

\section{Introduction}

Ozone is widely used in the industrial and environmental processes such as semiconductor manufacturing, deodorization, disinfection and water treatment [16]. The residual ozone must be removed because on the ground level it is an air contaminant [2]. Ozone is highly toxic in concentrations greater than $0.1 \mathrm{mg} / \mathrm{m} 3$ and it could harm the human health [13]. An effective method for purification of waste gases containing ozone is the heterogeneous catalytic decomposition [4]. Manganese oxide catalysts are of interest due to their applicability to catalytic reactions such as selective catalytic reduction of $\mathrm{NO}_{\mathrm{x}}$ with ammonia [11], $\mathrm{CO}$ oxidation [6] and combustion of organic compounds [17] in gaseous phase and selective oxidation of organic compounds [8] in liquid phase. Manganese oxide catalysts are also useful for the decomposition of ozone in gas streams [19]. Titanium dioxide is already known as catalyst support $[10,14]$ and also has been used as catalyst for several chemical reactions including decomposition of aqueous ozone [12, 19], photocatalytic decomposition of ozone [14] and catalytic ozonation of naproxen and carbamazepine [15]. X-ray diffraction (XRD) [16], IR spectroscopy [17], temperature programmed reduction (TPR) [18] and atomic force microscopy (AFM) [19] are popular techniques that have been used to characterize bulk, modified and supported manganese oxides.

The aim of present study is to investigate the catalytic activity of titania-supported manganese oxide system during heterogeneous catalytic decomposition of ozone and to determine its composition and surface properties using different physical methods for analysis.

\section{Experimental}

Manganese oxide catalysts $(6,8$ and 10 $w t \%)$ were prepared using aqueous solutions of manganese acetate $\left(\mathrm{Mn}\left(\mathrm{CH}_{3} \cdot \mathrm{COO}\right)_{2} \cdot 4 \mathrm{H}_{2} \mathrm{O}\right.$, BDH Chemicals $>99.99 \%$ ). $\mathrm{TiO}_{2}$ (Degussa, Aeroxid P25) has been used to support it. The synthesized catalytic samples contained 5.5, 7.4 and $9.3 \%$ molar percentages respectively on the $\mathrm{TiO}_{2}$ support. These values were calculated on the basis of assumption that $\mathrm{MnO}_{2}$ was formed on the support surface. At every synthesis the support was impregnated with precursor solution to the point of incipient wetness determined in separate measurements. After impregnation, all samples were heated at $393 \mathrm{~K}$ for 6 hours and calcinated at $773 \mathrm{~K}$ for 6 hours to produce $\mathrm{MnO}_{\mathrm{x}} /$ $\mathrm{TiO}_{2}$ (Fig. 1).

The catalysts were granulated and contained cylindrical grains with diameter of about $9 \mathrm{~mm}$ and thickness of $3 \mathrm{~mm}$. The kinetic measurements were carried out in a glass tube reactor $(10 \times 125 \mathrm{~mm})$ filled in with $0.3-0.6 \mathrm{~g}$ of catalyst. Fig. 2 shows the scheme of the experimental setup for all kinetics.

The kinetic measurements of ozone degradation were performed at flow rates ranging from 6.0 to $24 \mathrm{l} \mathrm{h}^{-1}$ and ozone concentration - from 1.0 to $1.2 \mathrm{mM}$. Ozone was generated by passing dry oxygen through a highvoltage silent-discharge ozone generator. Ozone concentration about $1 \mathrm{mM}$ was obtained at 15 $20 \mathrm{kV}$. The inlet and outlet ozone concentrations were monitored using an UV absorption-type ozone analyzer at $300 \mathrm{~nm}$.

The specific surface area of the catalyst $\left(72 \mathrm{~m}^{2} / \mathrm{g}\right)$ was measured by $\mathrm{N}_{2}$ adsorptiondesorption isotherms at $77 \mathrm{~K}$ using BET method in a FlowSorb 2300 instrument (Micromeritics Instrument Corporation). IR studies were performed in the transmittance mode using a Nicolet 6700 FT-IR spectrometer (Thermo Electron Corporation). A mixture of $\mathrm{KBr}$ and manganese oxide catalyst (100:1) was milled manually in an agate mortar before the preparation of pellets. The spectra were obtained by averaging 50 scans with $0.4 \mathrm{~cm}^{-1}$ resolution. 


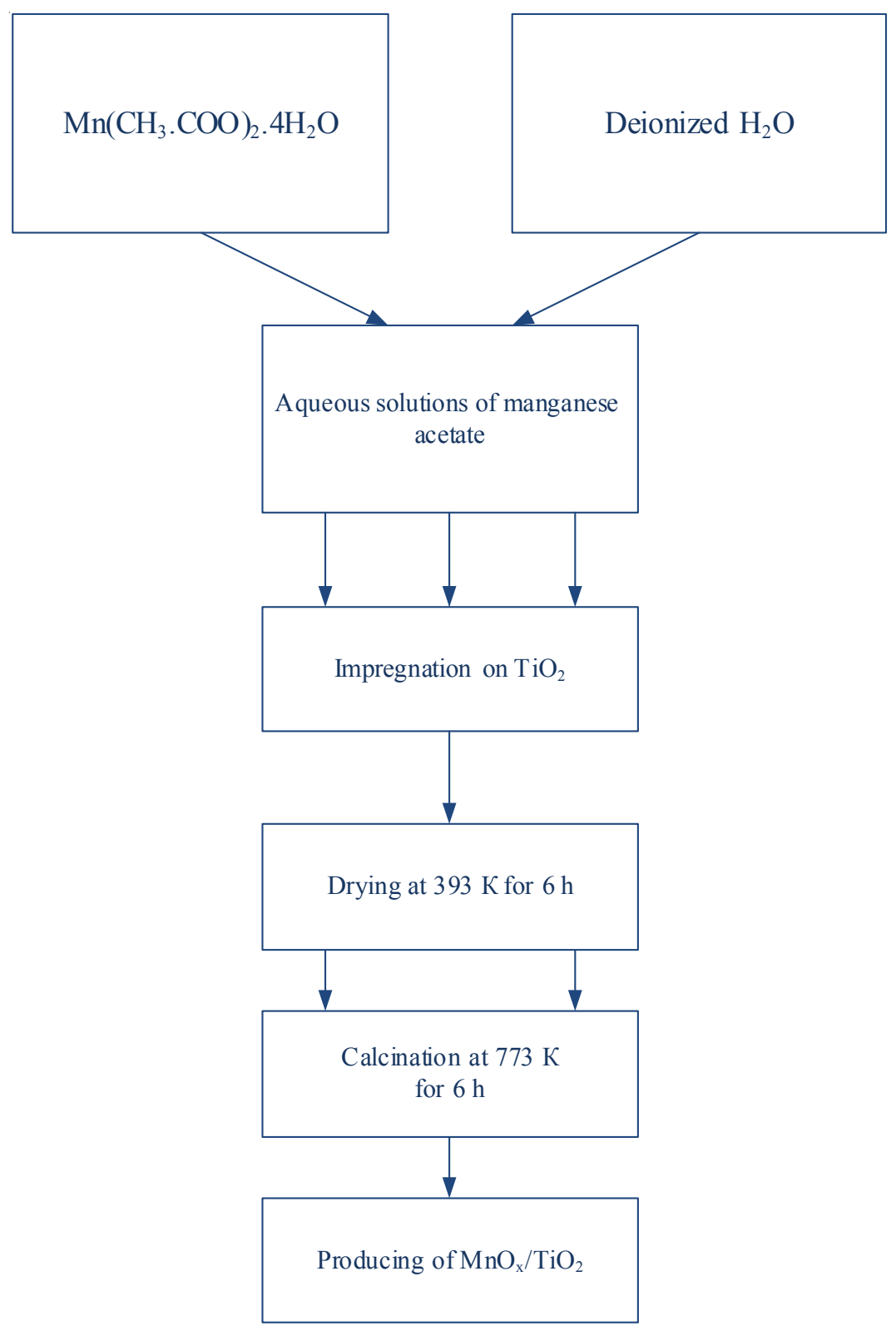

Fig. 1. Synthesis of $\mathrm{MnO}_{x} / \mathrm{TiO}_{2}$ catalyst

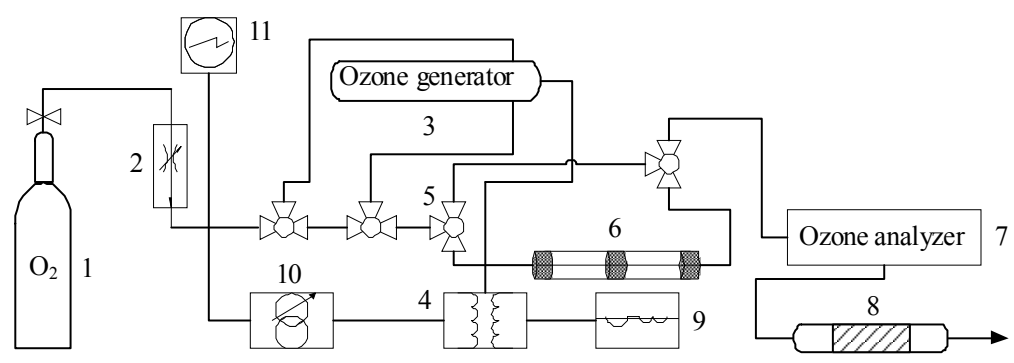

Fig. 2. Experimental set-up of reaction system for catalytic decomposition of ozone: 1 -oxygen; 2 - flow controller; 3 - ozone generator; 4 - transformer; 5 - three way turn cock; 6 - reactor charged with catalyst sample; 7 - Ozone analyzer; 8 - reactor for decomposition of residual ozone; 9 - current stabilizer; 10 - autotransformer; 11 - voltmeter 
A typical TPR experiment is done by passing a $\mathrm{H}_{2}$ stream over a catalyst while it is heated linearly and monitoring the consumption of $\mathrm{H}_{2}$ with a thermal conductivity detector or mass spectrometer. In our study a $10 \% \mathrm{H}_{2} /$ Ar mixture was used and the consumption of $\mathrm{H}_{2}$ was monitored using a thermal conductivity detector. A linear heating rate of $0.17 \mathrm{~K} \mathrm{~s}^{-1}$ was used for the experiment.

$\mathrm{X}$-ray diffraction (XRD) analysis was used to determine the crystalline metal oxide phases for the supported catalyst. A Bruker D8 Advance powder diffractometer with $\mathrm{Cu} \mathrm{Ka}$ radiation source and SolX detector was used. The samples were scanned from $2 \mathrm{q}$ angles of $10^{\circ}$ to $80^{\circ}$ at a rate of $0.04^{\circ} \mathrm{s}^{-1}$. The $\mathrm{X}$-ray power operated with a current of $40 \mathrm{~mA}$ and a voltage of $45 \mathrm{kV}$.

Atomic force microscopy (AFM) measurement was carried on Veeco Multimode scanning probe microscope instrument in taping mode.

\section{Results and Discussion}

The catalytic activity was evaluated on the basis of the coefficient $\gamma[20]$ that is proportional to ozone decomposition rate and to catalyst efficiency. It has been already used in other studies $[21,22]$ :

$$
\gamma=\frac{4 \omega}{\mathrm{V}_{\mathrm{t}} \mathrm{S}} \ln \frac{\left[\mathrm{O}_{3}\right]_{0}}{\left[\mathrm{O}_{3}\right]}
$$

where $\omega$ is the flow rate, $V_{t}$ - specific heat rate of ozone molecules, $\mathrm{S}$ - geometrical surface of catalyst sample and $\left[\mathrm{O}_{3}\right]_{0}$ and $\left[\mathrm{O}_{3}\right]$ - inlet and outlet ozone concentrations, respectively.
Fig. 3 presents the comparative activities of 6,8 and $10 \mathrm{wt} \%$ manganese oxide catalysts on support $\mathrm{TiO}_{2}$ during the decomposition of ozone produced from pure oxygen under dry conditions. The experiments were carried out with ozone flow rate in the range 6-24 $1 \mathrm{~h}^{-1}$ at room temperature.It was found that all three types of catalytic samples are active in the process of ozone decomposition. However we can see that the catalyst which contains $10 \mathrm{wt} \%$ manganese oxide showed the highest catalytic activity whereas the results for the other two catalysts are inconsistent and we could not say which one is more effective in ozone decomposition. The total ozone flow influence on catalytic activity concerning the $8 \mathrm{wt} \% \mathrm{MnO}_{\mathrm{x}} / \mathrm{TiO}_{2}$ catalyst is lower compared to the other two catalysts where the increase of ozone decomposition activity with total ozone flow enhancement was observed.

On Fig. 4 the changes in the decomposition coefficient $\gamma$ values in dependence on temperature of the catalytic reaction are shown. The ozone was decomposed over $10 \mathrm{wt} \%$ manganese oxide supported on titanium dioxide. The total ozone flow in all experiments was $61 \mathrm{~h}^{-1}$ and the temperature range - from $258 \mathrm{~K}$ to $313 \mathrm{~K}$. The graphic is presented in Arrhenius coordinates because we would like to find the activation energy of the process of ozone decomposition. On this graphic we could see a stable catalytic activity of the samples and growth of that activity with the growth of the temperature. The measured activation energy of the process of ozone decomposition over manganese oxide catalyst supported on titanium dioxide is $11 \mathrm{~kJ} / \mathrm{mol}$. This value is very close to some literature data [10] for similar catalytic samples.

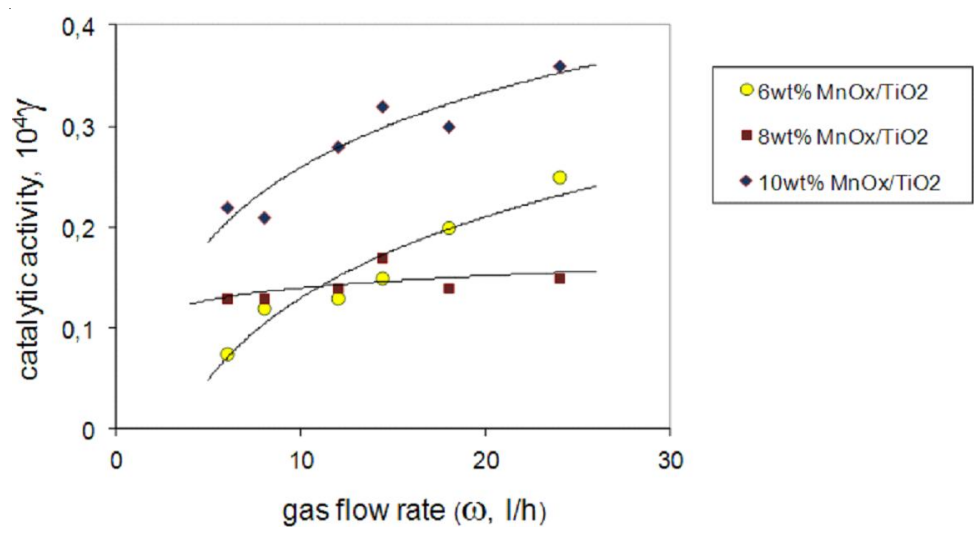

Fig. 3. Catalytic activity of 6,8 and $10 \mathrm{wt} \% \mathrm{MnO}_{\mathrm{x}} / \mathrm{TiO}_{2}$ in ozone decomposition 


\section{ТЕХНИКО-ТЕХНОЛОГИЧЕСКИЕ ИННОВАЦИИ}

The X-ray analysis results for the investigated catalyst are shown in Fig. 5. The diffractogram for the $\mathrm{MnO}_{\mathrm{x}} / \mathrm{TiO}_{2}$ sample showed peaks with large intensities at different values of $2 \mathrm{q}$ angle. The peaks at $23^{\circ}, 33^{\circ}, 45.1^{\circ}$ and $65.6^{\circ}$ correspond to manganese oxide phase $\mathrm{Mn} 2 \mathrm{O} 3$. The diffraction features at $27.5^{\circ}, 35.9^{\circ}, 41.2$ and $54.4^{\circ}$ are indicative of rutile $\mathrm{TiO}_{2}$. The catalyst sample at $25.3^{\circ}$ is due to another mineral form of $\mathrm{TiO}_{2}$-anatase.

The reducibility of the supported manganese oxide catalyst and the influence of the support over the catalyst were found by TPR experiment. The peak temperatures of reduction in Fig. 6 are $444 \mathrm{~K}, 596 \mathrm{~K}$ and $745 \mathrm{~K}$ for the supported catalyst and $824 \mathrm{~K}$ for the pure support. This shows that $\mathrm{MnO}_{\mathrm{x}}$ is well dispersed on the support and the oxide-support interaction is moderate.
FT-IR spectra of the manganese-oxide catalyst before ozone decomposition (a) and after ozone decomposition (b) are presented in Fig. 7. The spectra are almost identical, showing that the catalyst structure is not altered during the catalytic reaction. The broad adsorption band at $3446 \mathrm{~cm}^{-}$ ${ }^{1}$ appears from the stretching vibration of hydrogen bonded hydroxyl groups [21]. The adsorption band at $1628 \mathrm{~cm}^{-1}$ is due to the vibrations of water molecules [22]. The intensive band at $650 \mathrm{~cm}^{-1}$ appears at higher manganese concentrations and, in accordance with literature, can be attributed to well-defined metal oxide phase [16].

A catalytic cycle of ozone decomposition on $\mathrm{MnO}_{\mathrm{x}} / \mathrm{TiO}_{2}$ catalyst is proposed in Fig. 8 . This cycle is based on a probable mechanism of catalytic ozone decomposition described notably in paper [10] and also in several

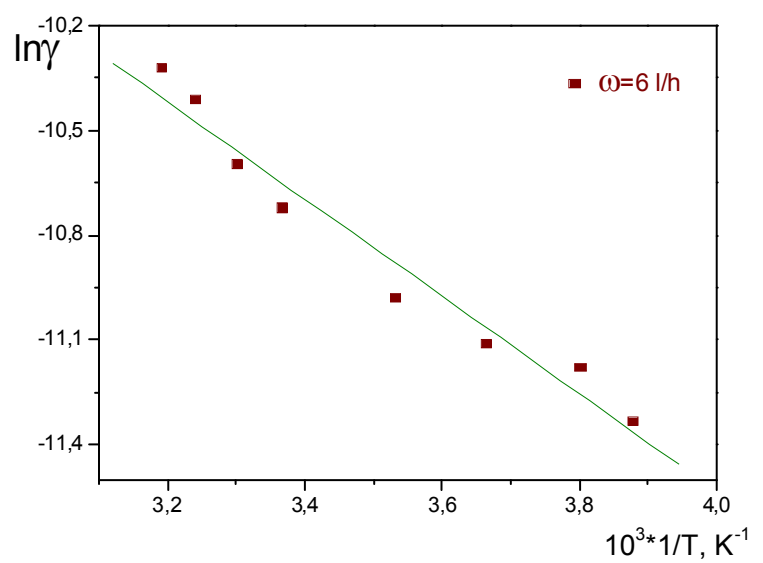

Fig. 4. Temperature dependence of catalytic activity at dry conditions in presence of $10 \mathrm{wt} \%$ manganese oxide supported on titanium dioxide, temperature range $258-313 \mathrm{~K}, \mathrm{O}_{3} / \mathrm{O}_{2}$ flow rate $61 \mathrm{~h}^{-1}$

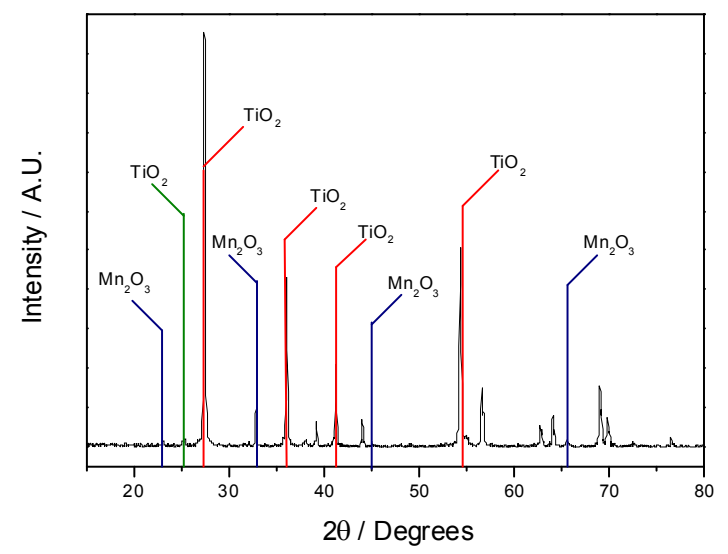

Fig. 5. X-ray diffraction of $\mathrm{MnO}_{\mathrm{x}} / \mathrm{TiO}_{2}$ catalyst 


\section{ТЕХНИКО-ТЕХНОЛОГИЧЕСКИЕ ИННОВАЦИИ}

articles $[23,24]$. The transformation of the manganese site from species (I) to (III) is indicative of an oxidation reaction. The structure numbered (II) in Fig 8 is probably a transition state for this first step in the ozone decomposition process. The transformation of species (III) to species (VI) in the proposed catalytic cycle is represented by the redox reaction: $\mathrm{O}_{3}+\mathrm{Mn}^{4+}+\mathrm{O}^{2-} \rightarrow \mathrm{O}_{2}+\mathrm{O}_{2}{ }^{2-}+\mathrm{Mn}^{4+}$. The transition states for this reaction are species (IV) and (V) presented in the catalytic cycle. Finally, the transformation of species (VI) to (I) in the catalytic cycle is a desorption step and the redox reaction for this step is: $\mathrm{Mn}^{4+}+$ $\mathrm{O}_{2}{ }^{2-} \rightarrow \mathrm{O}_{2}+\mathrm{Mn}^{2+}$.
In Figures 9A and 9B we show 2D and 3D AFM images of the $8 \mathrm{wt} \% \mathrm{MnOx} / \mathrm{TiO}_{2}$ catalyst thermally treated at $773 \mathrm{~K}$ for 2 hours in air atmosphere. The AFM results presented here give an estimation of the catalyst surface roughness. The images demonstrate the validity of our preparation method for the synthesis of heterogeneous catalysts for ozone decomposition with advanced pores and active sites distribution. Surface roughness increases the effective surface area of the material. Fig. 9A reveals the morphology of the modified titanium dioxide obtained by the AFM. The sample is composed of tightly packed regular particles stacked in a very rough catalytic surface.

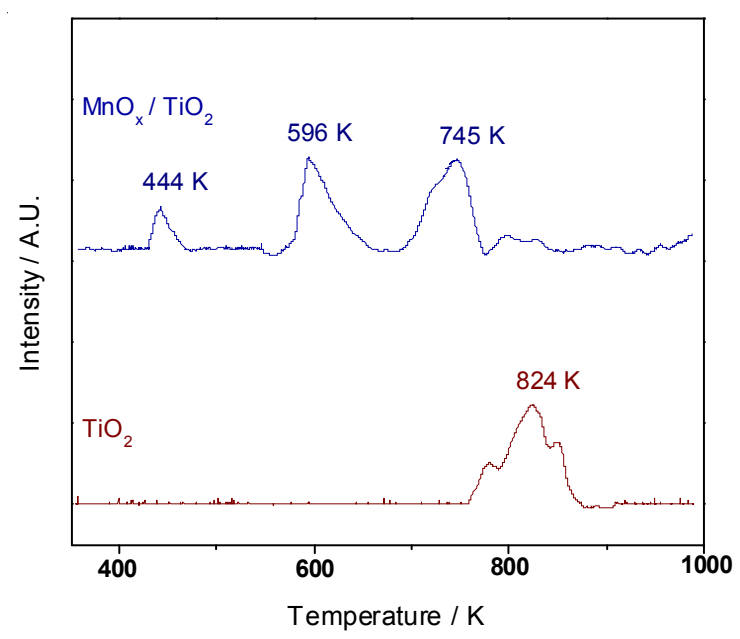

Fig. 6. TPR spectra of $\mathrm{MnO}_{x} / \mathrm{TiO}_{2}$ catalyst and pure $\mathrm{TiO}_{2}$ support

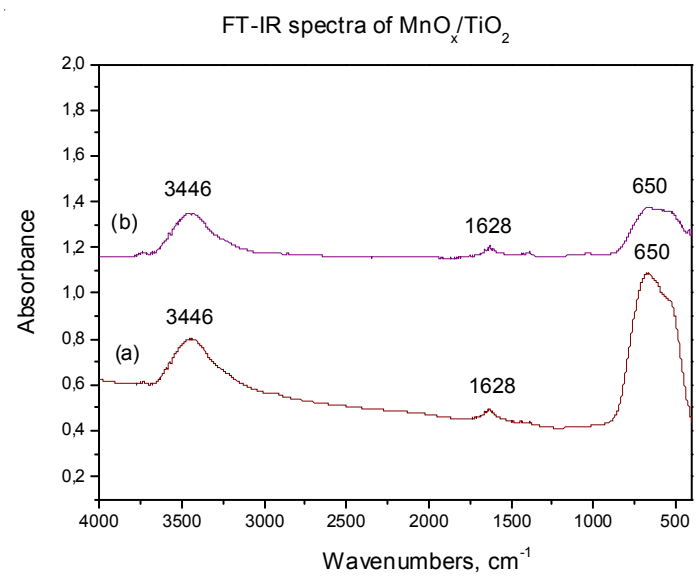

Fig. 7. FT-IR spectra of $\mathrm{MnO}_{x} / \mathrm{TiO}_{2}$ catalyst 


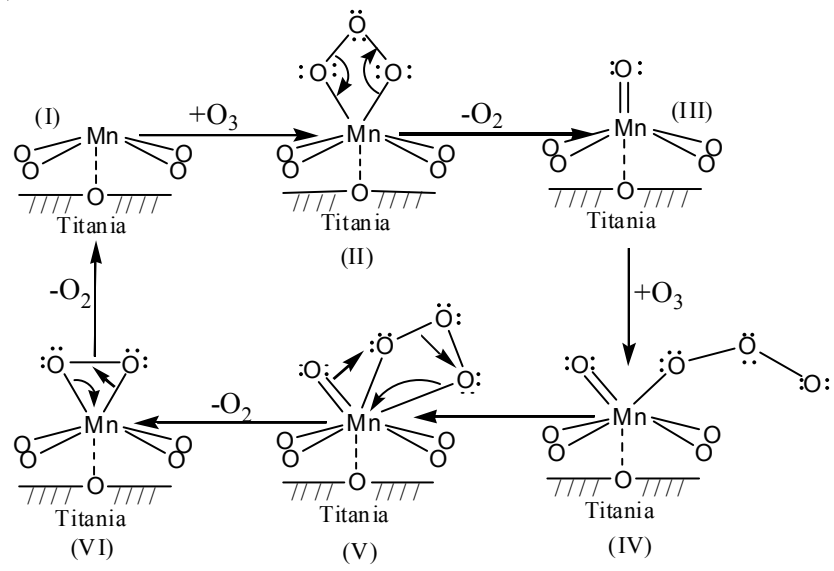

Fig. 8. Catalytic cycle of ozone decomposition on $\mathrm{MnO}_{x} / \mathrm{TiO}_{2}$ catalyst

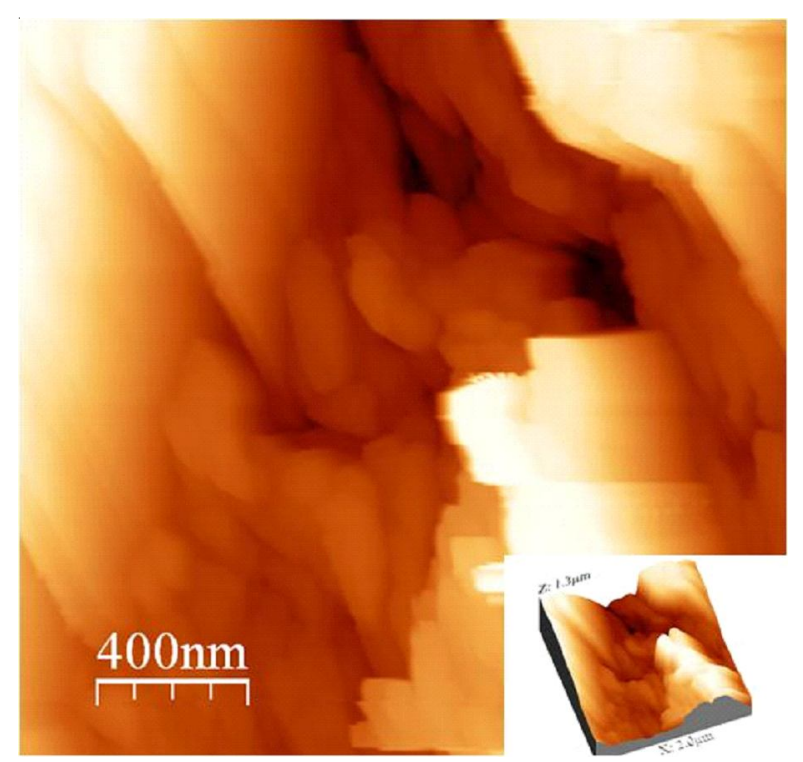

Fig. 9A. AFM image of $8 \mathrm{wt} \% \mathrm{MnO}_{x} / \mathrm{TiO}_{2}$ catalyst

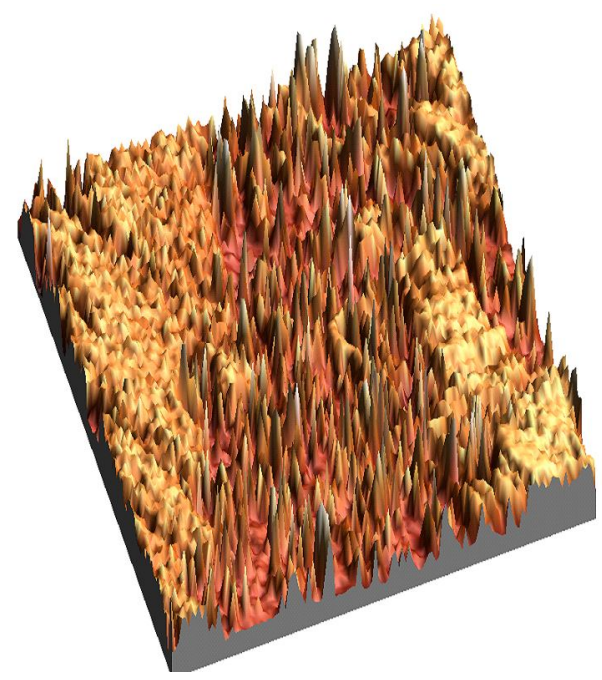

Fig. 9B. 3D AFM image of $8 \mathrm{wt} \% \mathrm{MnO}_{\mathrm{x}} / \mathrm{TiO}_{2}$ catalyst 


\section{Conclusions}

1. The catalyst owns high activity that is not change dramatically by varying temperature and flow rates.

2. The TPR spectra show that manganese oxide is well dispersed on the support and the oxide-support interaction is moderate.

3. The metal oxide phases in catalyst are identified using XRD analysis and the stability of the catalyst structure is proved with FT-IR analysis.

4. The proposed catalytic cycle reveals the important role of the peroxide species in ozone decomposition process.

5. Studies of atomic force microscopy (AFM) evidenced strong influence of preparation methods and pre-treatment conditions on the structural and catalytic properties of the samples.

\section{REFERENCES}

1. Baron A.A, Bakhracheva Yu.S, Osipenko A. Fracture Toughness Estimation by Means of Indentation Test. Mechanika, 2007, vol. 67, no. 5, pp. 33-36.

2. Baron A.A., Gevlich D.S., Bakhracheva Yu.S. Specific Plastic Strain Energy as a Measure of the Cracking Resistance of Structural Materials. Russian metallurgy (Metally), 2002, no. 6, pp. 587-592

3. Brown T.L., Lemay H.E., Bursten B.E., Burdge J.R. "22" in Nicole Folchetti Chemistry: The Central Science. $9^{\text {th }}$ ed. Pearson Education, 2003, pp. 882-883.

4. Buciuman F., Patcas F., Craciun R., Zhan D.R.T. Vibrational Spectroscopy of Bulk and Supported Manganese Oxides. Phys. Chem., 1998, no. 1, p. 185.

5. Dhandapani B., Oyama S.T. Gas Phase Ozone Decomposition Catalysts. J. Appl. Catal. B: Environmental, 1997, vol. 11, p. 129.

6. Einaga H., Ogata A. Benzene Oxidation With Ozone Over Supported Manganese Oxide Catalysts: Effect of Catalyst Support and Reaction Conditions. J. Hazard. Mater., 2008, vol. 164, p. 1236.

7. Fillaux F., Cachet C. H., Ouboumour H., Tomkinson J., Lévy-Clément C., Yu L.T. Inelastic Scattering Study of the Proton Dynamics in Manganese Oxides I - $\gamma-\mathrm{MnO} 2$ and Manganite. J. Electrochem. Soc., 1993, vol. 140, p. 585.

8. Gac W. The Influence of Silver on the Structural, Redox and Catalytic Properties of the Cryptomelane-Type Manganese Oxides in the LowTemperature CO Oxidation Reaction. Applied Catalysis B: Environmental, 2007, vol. 75, p. 107.

9. Ghosh R., Son Y.C., Makwana V.D., Suib S.L. Liquid-Phase Epoxidation of Olefins by Manganese
Oxide Octahedral Molecular Sieves. Journal of Catalysis, 2004, vol. 224, p. 288.

10. Hunter P., Oyama S.T. Control of Volatile Organic Compound Emissions, Conventional and Emerging Technologies. New York, Wiley, 2000.

11. Kapteijn F., Van Langeveld A.D., Moulijn J.A., Andreini A., Vuurman M.A., Turek M.A., Jehng J. M., Wachs I.E. Alumina-Supported Manganese Oxide Catalysts. J. Catal., 1994, vol. 150, p. 94.

12. Kijlstra W.S., Brands D.S., Poels E.K., Bliek A. Mechanism of the Selective Catalytic Reduction of NO by NH3 over MnOx/A12O3. J. Catal., 1997, vol. 171, p. 208.

13. Lin J., Kawai A., Nakajima T. Effective Catalysts for Decomposition of Aqueous Ozone. J. Appl. Catal. B: Environmental, 2002, vol. 39, p. 157.

14. Lunin V.V., Popovich M.P., Tkachenko S.N. Physical Chemistry of Ozone. Moscow, Moscow University Publ. House, 1998, pp. 377-444.

15.Ma J., Chuah G. K., Jaenicke S., Gopalakrishnan R., Tan K.L. Catalysis by Manganese Oxide Monolayers. Part 1: Alumina and Magnesia Supports, Ber.Bunsenges. Phys. Chem., 1995, vol. 100, p. 585.

16. Muruganandham M., Chen S.H., Wu J.J. Evaluation of Water Treatment Sludge as a Catalyst for Aqueous Ozone Decomposition. Catalysis Communications, 2007, vol. 8, p. 1609.

17. Ohtani B., Zhang S., Nishimoto S., Kagiya T. Catalytic and Photocatalytic Decomposition of Ozone at Room Temperature Over Titanium (IV) Oxide. J. Chem. Soc., 1992, vol. 88, p. 1049.

18. Oyama S.T. Chemical and Catalytic Properties of Ozone. Catal. Rev. Sci. Eng., 2000, vol. 42, p. 279.

19. Puckhaber L.S., Cheung H., Cocke D.L., Learfield A. Reactivity of Copper Manganese Oxides. Solid State Ionics, 1989, vol. 32/33, p. 206.

20. Radhakrishnan R., Oyama S.T., Chen J., Asakura A. Electron Transfer Effects in Ozone Decomposition on Supported Manganese Oxide. J. Phys. Chem. B, 2001, vol. 105 (19), p. 4245.

21. Rakovsky S., Zaikov G. Kinetic and Mechanism of Ozone Reactions with Organic and Polymeric Compounds in Liquid Phase. $2^{\text {nd }}$ ed. New York, Nova Science Publishers Inc., 2007, pp. 1-340.

22. Reed C., Xi Y., Oyama S.T. Distinguishing Between Reaction Intermediates and Spectators: a Kinetic Study of Acetone Oxidation Using Ozone on a Silica-Supported Manganese Oxide Catalyst. J. Catal., 2005, vol. 235, p. 378.

23. Rosal R., Rodriguez A., Gonzalo M. S., Garcia-Calvo E. Catalytic Ozonation of Naproxen and Carbamazepine on Titanium Dioxide. J. Appl. Catal. B: Environmental, 2008, vol. 84, p. 48.

24. Semenova L.M., Bakhracheva Yu.S., Semenov S.V. Laws of Formation of Diffusion Layers 


\section{ТЕХНИКО-ТЕХНОЛОГИЧЕСКИЕ ИННОВАЦИИ}

and Solution of the Diffusion Problem in TemperatureCycle Carbonitriding of Steel. Metal Science and Heat Treatment, 2013, vol. 55, no. 1-2, pp. 34-37.

25. Shapochkin V.I., Semenova L.M., Bakhracheva Yu.S., Gyulikhandanov E.L., Semenov S.V. Effect of Nitrogen Content on the Structure and Properties of Nitrocarburized Steel. Metal Science and Heat Treatment, 2011, vol. 52, no. 910, pp. 413-419.

26. Stoyanova M., Konova P., Nikolov P., Naydenov A., Christoskova S., Mehandjiev D.
Alumina-Supported Nickel Oxide for Ozone Decomposition and Catalytic Ozonation of $\mathrm{CO}$ and VOCs. Chem. Eng. Journal, 2006, vol. 122, p. 41.

27. Subrahmanyam C., Bulushev D., KiwiMinsker L. Dynamic Behaviour of Activated Carbon Catalysts During Ozone Decomposition at Room Temperature. J. Appl. Catal. B: Environmental, 2005, vol. 61, p. 98.

28. Xi Y., Reed C., Lee Y.-K., Oyama S.T. Acetone Oxidation Using Ozone on Manganese Oxide Catalysts. J. Phys. Chem. B, 2005, vol. 109, p. 17587.

\section{АКТИВНОСТЬ ТИТАНОВОГО КАТАЛИЗАТОРА ОКСИДА МАГНИЯ ПРИ РАЗЛОЖЕНИИ ОЗОНА \\ Батаклиев Тодор Тодоров}

Доцент, кандидат наук,

Институт катализа болгарской Академии наук

todor@ic.bas.bg

ул. Академика Г. Бончева, 11, 1113 г. София, Болгария

\section{Раковский Славико Кирилов}

Профессор, доктор наук,

Институт катализа болгарской Академии наук

rakovsky@ic.bas.bg

ул. Академика Г. Бончева, 11, 1113 г. София, Болгария

\section{Заиков Геннадий Ефремович}

Доктор химических наук, профессор, заведующий отделом биологической и химической физики полимеров, Институт биохимической физики им. Н.М. Эмануэля РАН chembio@sky.chph.ras.ru ул. Косыгина, 4, 119334 г. Москва, Российская Федерация

\section{Георгиев Владимир Фердинандов}

Доцент, кандидат наук,

Институт катализа болгарской Академии наук

vlado@ic.bas.bg

ул. Академика Г. Бончева, 11, 1113 г. София, Болгария

\section{Аначков Мефодий Пырванов}

Доцент, кандидат юридических наук,

Институт катализа болгарской Академии наук

anachkov@ic.bas.bg

ул. Академика Г. Бончева, 11, 1113 г. София, Болгария 
Аннотация. Авторами было установлено, что каталитическая активность всех образцов зависела от скорости разложения озона, но самым активным был катализатор, обладающий $\mathrm{MnOx} / \mathrm{TiO} 2$. Расчетные значения были в диапазоне $0.05 \times 10^{-4} \times 10^{-4}$. Эксперименты проводились в температурном диапазоне от 258 к до $313 \mathrm{~K}$. Было установлено, что энергия активации процесса составляет 11 кДж/моль.

Ключевые слова: озон, диоксид титана, оксид марганца, разложение, энергия активации. 